\title{
Research on the Training Mode of Intelligent Manufacturing Teachers Under the Mode of University Enterprise Cooperation
}

\author{
Zhou Renbin, Wan Qiang \\ Institute of Mechatronics and Automation, Wuchang Shouyi University, Wuhan, China \\ Email address: \\ zrbwy2001@163.com (Zhou Renbin),4776974@qq.com(Wan Qiang)
}

To cite this article:

Zhou Renbin, Wan Qiang. Research on the Training Mode of Intelligent Manufacturing Teachers Under the Mode of University Enterprise Cooperation. Education Journal. Vol. 8, No. 6, 2019, pp. 354-358. doi: 10.11648/j.edu.20190806.28

Received: October 31, 2019; Accepted: December 4, 2019; Published: December 9, 2019

\begin{abstract}
With the in-depth development of market economy and the "explosive" surge of demand for high-quality compound talents in the era of information and intelligence, strengthening the cooperation between universities and enterprises has become an inevitable choice for colleges and universities, especially private Application-oriented College Students. The mode of university enterprise cooperation is a process in which both universities and enterprises participate in talent training. The integration of industry and education and the cooperation between universities and enterprises are the fundamental direction of the educational reform and dynamic development of the application-oriented universities. Through the research on the training mode of intelligent manufacturing professional teachers under the mechanism of university enterprise production learning combined with collaborative education, innovation has been realized in the training mode of intelligent manufacturing professional teachers, professional leaders have been selected and trained, backbone teachers have been trained, and the "double teacher" type teachers have reached $100 \%$. It has been proved by practice that the exploration of the training mode of intelligent manufacturing teachers under the mechanism of university enterprise production learning combined with collaborative education can promote the teaching, practice, scientific research and social service ability of all teachers in the university, and promote the professional growth of teachers.
\end{abstract}

Keywords: Combination of Production and Study, Cooperative Education, Intelligent Manufacturing, Teacher Training Mode

\section{Introduction}

With the in-depth development of market economy and the "explosive" surge in demand for high-quality composite talents in the era of information and intelligence, strengthening the cooperation between University and enterprise has become an inevitable choice for colleges and universities [1-5], especially for private Application-oriented College Students. The mode of university enterprise cooperation is a process in which both University and enterprises participate in talent training [6-7]. The integration of industry and education and the cooperation between universities and enterprises are the fundamental direction of the reform and development of applied university education. As a national pilot University of "transformation of applied technology-based ordinary universities", and as the Ministry of education "Internet + China made 2025" teaching and learning integration and promotion pilot institutions,
Wuchang Shouyi University actively explores a new model of teacher training, which is characterized by university enterprise cooperation, multi participation and flexible and open, and deeply constructs a mechanism of integration of production and education, and the combination of university enterprise [8-12], industry and learning, so as to integrate multiple forces and resources, improve the quality of teacher training, and promote the healthy development of applied undergraduate education, which can effectively solve the bottleneck of insufficient teacher resources in the connection of talent training and social needs problem.

\section{Training Background of University Enterprise Collaborative Intelligent Manufacturing Professional Teachers}

The cultivation of compound talents needs a compound 
teaching team. College teachers need not only solid theoretical knowledge, but also strong practical ability and scientific research ability [13-15]. For a long time, Wuchang Shouyi University adheres to the scientific orientation of cultivating "high-quality application-oriented" talents. Through international cooperation in running universities, efficient linkage between University and enterprises, and deep integration of production and education, it strives to cultivate applicable talents with perfect personality, sound mind, excellent professional core competence and courage to practice and innovate. However, intelligent manufacturing, industrial robots and other new specialties are newly established in recent years. The actual number of professional teachers is insufficient, the curriculum burden is serious, the teachers lack the actual production experience of the enterprise, and the practical ability of the actual production process of the enterprise needs to be further strengthened. The improvement and optimization of the overall teacher strength is an urgent bottleneck problem to be solved in the professional development.

Beijing Huacheng Jingshi Information Technology Co., Ltd. (hereinafter referred to as "Huasheng Jingshi Company") is an educational technology enterprise facing the future. It is committed to transforming advanced technology into educational technology, integrating technology and services, innovating education methods and ecology, integrating the leading technology of the industry and the equipment of the leading enterprises in the whole world, and using the professional education team and the Internet + technology platform to make enterprise capital. By introducing universities, Yuan yuan has realized the deep integration of global leading enterprises and professional development, formed a collaborative network connecting cooperative colleges and universities, and built a one-stop industry-oriented integrated education service platform.

In order to thoroughly implement the spirit of the national education conference, earnestly implement the requirements of the opinions of the general office of the State Council on deepening the innovation and entrepreneurship education reform of institutions of higher learning (GBF [2015] No. 36) and the opinions of the general office of the State Council on deepening the integration of industry and Education (GBF [2017] No. 95), deepen the integration of industry and education, the cooperation of industry and education, and the collaborative education of talents, Since 2017, Wuchang Shouyi University and Huasheng Jingshi company have strengthened the research on the teacher training mode of Intelligent Manufacturing Specialty under the mode of university enterprise production learning combination and collaborative education. Through the combination of engineering and learning, university enterprise cooperation, production learning cooperation and collaborative education, they have strengthened the construction of teachers' strength, the combination of teaching and production, and the mutual support, mutual penetration, two-way intervention and excellence of both University and enterprises. To realize the modernization of Applied Undergraduate Education and enterprise management, promote the development of productivity, make education and production sustainable development, and realize the mutual benefit of university enterprise teachers sharing.

\section{Requirements for the Training of Teachers in University Enterprise Collaborative Intelligent Manufacturing}

Through the combination of university enterprise production and university education, Wuchang Shouyi University strengthens the introduction, training, evaluation and employment of professional teachers, improves the management system of full-time and part-time teachers, establishes the university enterprise talent sharing mechanism, and constantly increases the efforts of work and capital investment. This paper puts forward the goal of "121" teacher training, taking "professional leader" as the teaching and practice leader, taking "backbone teacher" as the middle force, taking "Double Teachers" as the main teaching force, introducing part-time teachers, and employing experts in the industry to guide, so as to strengthen the teaching team of junior college.

"121" teacher training objectives, specifically, the first is to select and cultivate a leader in intelligent manufacturing, so that the professional leader has the ability and level to integrate university enterprise professional teaching resources, design professional talent training programs, and lead professional development; The second is to train two backbone teachers, so that the backbone teachers have the ability to undertake the core curriculum construction of intelligent manufacturing and the development of university-based teaching materials. Third, according to the needs of intelligent manufacturing talents training mode, the combination of training and introduction is to strengthen the construction of teachers' team. Through the existing teachers to colleges and universities for further study and enterprise practice, and the introduction of part-time teachers and the employment of enterprise industry experts for guidance, the "double teacher" type teachers can reach $100 \%$.

\subsection{Training of Professional Leaders}

First, the university issued the training plan for professional leaders, determined the training objects and requirements of professional leaders, and established growth files; the second is to improve the quality of "Double Teachers". On the one hand, through participating in the technical training and examination of cooperative enterprises, on the other hand, organizing the training objects to participate in the national level training and overseas training in a planned way to learn advanced educational concepts and teaching methods; the third is to lead the major construction and curriculum resources development. To improve the level of professional construction and curriculum development by 
participating in special seminars on curriculum reform or going out to observe and study with cooperative enterprises; fourthly, to preside over the formulation of professional talent training program, the construction of main professional core curriculum, guide young teachers of the major, undertake professional teaching and research, scientific research projects, serve as professional core curriculum teaching, preside over the construction of core curriculum or the development of characteristic teaching materials, etc.

\subsection{Training of Key Teachers}

First, the second level college formulates the training plan for professional backbone teachers, focusing on the training of professional backbone teachers; second, it hires cooperation companies or other university experts to carry out special lectures in the university; organizes backbone teachers to visit and study in enterprises out of production, and to study in relevant colleges and Universities; third, it organizes teachers to practice in enterprises to form strong teaching or practical ability.

\subsection{The Construction of "Double Teacher" Teachers}

First, professional teachers are required to participate in practice in cooperative enterprises for more than one month every year; second, new teachers must practice in the new intelligent manufacturing professional training room and practice base of university enterprise cooperation for more than half a year; third, teachers are encouraged to participate in skill appraisal training; fourth, increase the strength of competition and guidance awards, and improve the level of guidance of teachers' skill competition; fifth, require all professional universities Teachers must participate in market research, core curriculum construction and university-based textbook development.

\subsection{Employment of Part-time Teachers}

According to the needs of professional development and teaching, two industry front-line personnel with certain theoretical level and strong professional skills are employed as part-time teachers, who can participate in some practical teaching or training guidance, carry out technical exchanges and skills training with on-the-job teachers, and play a role in on-the-job internship and student employment guidance of university enterprise cooperation middle university students.

\subsection{Experts of Industrial Enterprises}

According to the needs of professional development, 3-4 well-known experts are invited from intelligent manufacturing enterprises and colleges and universities to establish a professional construction Steering Committee. To guide the construction of talent training mode, curriculum system, teaching mode and evaluation mode reform, participate in the formulation of professional talent training program and ability standard, regularly attend lectures and carry out teacher training, and lead and check the direction of professional development.

\section{The Training Path of University Enterprise Collaborative Intelligent Manufacturing Professional Teachers}

In the past few years, with the effect of cooperation and cooperation among universities and collaborative enterprises, and the effect of resource integration and policy incentives, the "Internet $+"$ intelligent manufacturing and education integration and innovation practical teaching base has been built, and the intelligent manufacturing laboratory has been built. The teaching resources measures have been shared and the actual engineering projects of enterprises have been transformed into specific teaching projects, so that intelligent manufacturing professional teachers can participate in the project at different levels. The implementation process, the implementation of the concept of "science leads the project, the project into the classroom", comprehensively pushes teachers to the "double teacher" quality, improve the effectiveness of education.

\subsection{University and Enterprises Jointly Build Joint Efforts to Create "Internet +" Intelligent Manufacturing and Teaching Integration and Innovation and Practice Teaching Base}

In 2016, Wuchang Shou Yi university was selected by the Ministry of education's university planning and development center, "Internet + China made 2025" pilot project for teaching and learning integration and promotion (one of the first 17 universities in the country). In 2017, the university signed a cooperation agreement with Huacheng Jingshi company to jointly build a practical teaching base for university enterprise cooperation, and build "Internet +" intelligent manufacturing, education, integration, innovation and practice teaching base and "intelligent manufacturing practice factory", providing a joint training mode of "industry university research integration". From scheme planning, site transformation, equipment installation and debugging, technical training and acceptance, relying on the international leading intelligent manufacturing technology and products, with enterprise standard process, the whole process of design, production, debugging, operation and construction of the intelligent manufacturing plant is fully reproduced in the construction, to create an integrated platform of practical teaching, scientific research innovation and service, and to provide first-class teaching and scientific research services for teachers and students.

\subsection{University Enterprise Resource Integration, Jointly Build a Series of Intelligent Manufacturing Experimental Training Platform}

Wuchang Shouyi university, Huasheng Jingshi company, Autodesk China company and other well-known enterprises jointly build intelligent manufacturing professional laboratory, It has successively established intelligent manufacturing laboratories such as industrial robot comprehensive training platform, factory data acquisition and 
monitoring control training system, advanced manufacturing and comprehensive training platform, numerical control practice base, etc., introduced intelligent manufacturing equipment technology and intelligent production management technology into practical teaching in the form of real engineering projects, closely connected with enterprise needs, and realized cutting-edge technology in teaching and manufacturing industry Synchronization of operation. Based on the service of enterprise engineers from the industry, the mode of in-depth integration of production and education is opened; teaching is oriented by the industry demand, with typical projects as the carrier, adopting the mode of "one course, two teachers", developing online and offline integrated teaching resources, providing educational technology products based on VR, cloud computing, big data and other technologies, and changing the way of learning, teaching and professional management, so as to promote education.

\subsection{University Enterprise Cooperation and Mutual Assistance to Realize the Sharing of Teachers and Teaching Resources}

By sending teachers of intelligent manufacturing specialty to advanced enterprises to learn cutting-edge technology, encouraging professional teachers to go to colleges and universities for further professional study, organizing professional teachers to practice in enterprises, etc., teachers are arranged to serve as visiting engineers in enterprises in winter and summer vacation, so as to practically do on-the-job work and participate in the production practice and project development process of enterprises. At the same time, excellent engineering and technical personnel are selected as part-time teachers to carry out teaching and skills training activities in universities, so as to realize the mutual benefit and sharing of university and enterprise teachers. Many of them build a professional teacher team in the direction of intelligent manufacturing. Through the construction of full-time and part-time teachers in University and enterprises, we can promote the cultivation of "double teacher" quality teachers in universities.

\subsection{University Enterprise Bilateral Policy Incentives to Promote All-round Transformation of Professional Teachers to Intelligent Manufacturing}

First, the college has issued a series of incentive policies to evaluate all teaching teachers, encourage existing teachers to actively participate in all kinds of competitions and examinations, reward teachers with higher teaching level in the direction of intelligent manufacturing, and increase the incentive for scientific research achievements in new disciplines such as intelligent manufacturing. Second, the enterprise cooperates with the university to organize all-round teaching competitions in intelligent manufacturing, digital manufacturing and other aspects, encourages teachers and students to create intelligent works in the form of teams, and constantly improves the application technology level of intelligent manufacturing. The university and the enterprise jointly organize the selection of intelligent innovative works, and Awards outstanding works.

\section{Conclusion}

Through the research on the cultivation mode of intelligent manufacturing professional teachers under the mechanism of university enterprise production learning combined with collaborative education, Wuchang Shouyi University has carried out in-depth cooperation with Huasheng Jingshi company and other enterprises, realized innovation in the cultivation mode of intelligent manufacturing professional teachers, selected and trained professional leaders, trained backbone teachers, introduced part-time teachers, hired enterprise industry experts, and cultivated and introduced the combination Together, make "double teacher" type teacher reach $100 \%$. It has been proved by practice that the exploration of the training mode of intelligent manufacturing teachers under the mechanism of university enterprise production learning combined with collaborative education can promote the teaching, practice, scientific research and social service ability of all teachers in the university, promote the professional growth of teachers, make positive contribution to the development of regional economy, and form good demonstration and radiation effect on other application-oriented universities.

\section{Acknowledgements}

This paper is one of the phased achievements of the collaborative education project of the Ministry of education of the People's Republic of China "Research on the cultivation of teachers of Intelligent Manufacturing Specialty under the mode of university enterprise industry university collaborative education" (201802048092).

\section{References}

[1] Research group of China Academy of education, research on improving talent training system in key fields of advanced manufacturing industry $[\mathrm{J}]$. Education research, 2016 (01): $4-16$.

[2] Huang Xiuhua, Huang Yongna, he Xingbo. The construction of numerical control teachers in the direction of intelligent manufacturing [J]. Modern economic information, 2019 (15): 423.

[3] Zhao Chuanbin. Thinking on the construction of the Faculty of Intelligent Manufacturing Specialty in the new era $[\mathrm{J}]$. Hubei agricultural mechanization, 2019 (06): 50-51.

[4] Ji Shuqing, Chen Zhangxia. A study on the construction system of "1133" top three teachers in hierarchical and classified training [J]. China Adult Education, 2018 (14): 141-142.

[5] Zhu Wenjie, Bing Zhigang, Li Li. The application of mind mapping in the training of vocational teachers in the context of intelligent manufacturing [J]. Journal of Tianjin Vocational and Technical Normal University, 2019, 29 (01): 64-68. 
[6] Fan Ning. Reflections on the construction of the Faculty of Intelligent Manufacturing Specialty in Higher Vocational Education [J]. Guangdong sericulture, 2018, 52 (07): 56.

[7] Pan Dong. Research on the demand and Countermeasures of numerical control technology professionals in the direction of intelligent manufacturing $[\mathrm{J}]$. Science and technology horizon, 2018 (24): 82-83.

[8] Liu Hongjiao, min min. personnel training of process equipment and control engineering in Local Universities under the background of intelligent manufacturing [J]. Light industry technology, 2019, 35 (03): 162-163.

[9] Zhang Lihua. Research on talent training of Intelligent Manufacturing "order class" [J]. Ship vocational education, 2019, 7 (04): 20-21 + 24 .

[10] Liu Xiaochun. Research on the training mode of intelligent talents of Automation Specialty in Higher Vocational Education under the background of intelligent manufacturing [J]. Shandong industrial technology, 2017 (17): 294-295.
[11] Tang Ling. Research on the cultivation of skilled talents based on "made in China 2025" [J]. Technology economy and management research, 2016 (06): 30-35

[12] Yi Zhongqi. Thinking on precise training of technical and technical talents for made in China 2025 [J]. Vocational education of machinery, 2017 (02): 1-3.

[13] Gao Hong. Ideas and paths to promote the construction of vocational education teachers in the new era $[\mathrm{J}]$. China Vocational and technical education, 2017 (34): 116-120.

[14] Liu Qianjing. Development of intelligent manufacturing industry and change of talent demand [J]. Education modernization, 2017, 4 (09): 11-12 + 17.

[15] Li Wei, Shi Weiping. A new exploration on the training standard and path of technical talents in the perspective of intelligent manufacturing $[\mathrm{J}]$. Vocational and technical education, 2017, 38 (19): 19-23. 